Note

\title{
GENETIC CONTROL OF SEED DORMANCY AND PRE- HARVEST SPROUTING IN WHEAT
}

\author{
Claudinei Andreoli*; Manoel Carlos Bassoi; Dionisio Brunetta \\ Embrapa Soja, C.P. 231 - 86061-970 - Londrina, PR, Brasil. \\ *Correspondencing author <andreoli@cnpso.embrapa.br>
}

\begin{abstract}
Pre-harvest sprouting (PHS) damage leads to occasional massive losses in all wheat producing areas, causing downgrading of grain quality, that severely limits end-use applications and results in substantial financial losses to farmers and food processors. Red grain color is a traditional marker for resistance to sprouting in wheat breeding programs, however red-grained genotype alone does not always guarantee effective resistance. The objective of this work was to find genes for resistance to PHS and investigate its inheritance in Brazilian wheat cultivars. Genetic variation for dormancy was investigated in the parents, $\mathrm{F}_{1}$ and $300 \mathrm{~F}_{2}$ lines derived from the cross Frontana $\times \mathrm{OR} 1$ and its reciprocal. The germination/ dormancy sprouted grains was evaluated on fifty seeds per replication, germinated in paper towel rolls at $20^{\circ} \mathrm{C}$ for 5 days. A bimodal distribution for dormancy occurred in the Frontana/OR 1 and OR1/Frontana derived $\mathrm{F}_{2}$ populations. The mean ratio of dormant and non-dormant seeds of the cross and its reciprocal was 85:1115, fitting a digenic model of 1:15 $(P<0.05)$. In fact, all non after-ripened $\mathrm{F}_{1}$ seeds germinated. The $\mathrm{F}_{2}$ distribution indicates that two major genes, here called $A, a$ and $B, b$, control seed dormancy, which it appears to be recessive to dormancy. Only the homozygous $a a b b$ is dormant. As expected, there was no effect of maternal tissues.

Key words: Triticum aestivum, QTL, $\alpha$-amylase, digenic model, phenotype
\end{abstract}

\section{CONTROLE GENÉTICO DA DORMÊNCIA E DA GERMINAÇÃO PRECOCE EM TRIGO}

\begin{abstract}
RESUMO: Germinação precoce na espiga (PHS) ocasiona perdas significativas nas regiões produtoras de trigo, causando depreciação na qualidade do produto final, o que resulta em prejuízos para os produtores e os moageiros. A cor vermelha do grão é um marcador tradicional para resistência à germinação nos programas de melhoramento de trigo, todavia, o genótipo de grão vermelho sózinho não garante resistência efetiva. O objetivo desse trabalho foi encontrar gene(s) para resistência à PHS e estudar a herança do caráter dormência de semente nos cultivares de trigo brasileiro. A variação genética para dormência foi investigada nos parentais, no $\mathrm{F}_{1}$ e em 300 linhas $\mathrm{F}_{2}$ derivadas do cruzamento de Frontana $\times$ OR1, e o cruzamento recíproco. Os grãos brotados (sprouted) e os dormentes foram avaliados pelo teste de germinação, em rolo de papel, a $20^{\circ} \mathrm{C}$ por 5 dias. Observou-se uma distribuição bimodal na população $\mathrm{F}_{2}$ para Frontana $\times$ OR 1 e OR $1 \times$ Frontana. A taxa segregante de sementes dormentes e não -dormentes foi de 85:1115, o que revela um modelo digênico de $1: 15(P<0,05)$. Na verdade, todas as sementes $\mathrm{F}_{1}$, $\log 0$ após a colheita, germinaram. Esse resultado e a distribuição $\mathrm{F}_{2}$ indicam que dormência parece ser recessiva e que há o envolvimento de dois genes, denominados de $A, a$ e $B, b$ controlando a dormência da semente de trigo. Somente o genótipo homozigoto $a a b b$ é dormente. Como esperado, não houve efeito dos tecidos maternais.
\end{abstract}

Palavras-chave: Triticum aestivum, QTL, $\alpha$-amilase, modelo digênico, fenótipo

\section{INTRODUCTION}

Pre-harvest sprouting (PHS) damage leads to occasional massive losses in all wheat (Triticum aestivum L.) producing areas, causing downgrading of grain quality that severely limits end-use applications and results in substantial financial losses to farmers and food processors. Lack of adequate dormancy results in pre-harvest sprouting in the field under wet weather conditions. Pre-harvest sprouting is the germination of the grains before harvest due to rainfalls and high humidity (Figure 1). During this process, it occurs an increase of $\alpha$-amylase activity in the endosperm, resulting in the degradation of starch to reduced sugars, which causes great losses to the bakery industry. Tolerance to sprouting damage and embryo dormancy is 


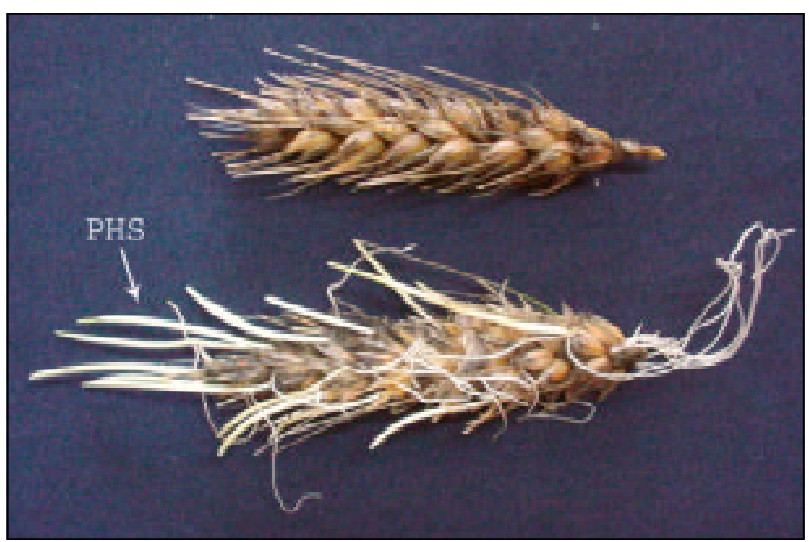

Figure 1 - Damage of pre-harvest sprouting in a highly susceptible cultivar, BR 18, after a period of rain in the field, and a highly resistant cultivar Frontona, in Londrina, State of Paraná, Brazil. 2004. The arrow shows the symptom of pre-harvest sprouting (PHS) in BR 18.

therefore a highly desirable but complex trait that is regulated by a number of key resistance genes that strongly interact with environmental conditions. Several workers have noted that seed dormancy appears to be closely associated with red grain color. However, PHS occurs sporadically in all red commercial varieties, implicating that the red-grained genotypes alone do not always guarantee effective resistance (Flintham $\&$ Gale, 1988; Flintham, 2000).

Lawson et al. (1997), who had worked with Australian background, showed that in two recombinant populations PHS was under a simple genetic control involving two genes. A new major gene (PHS) was identified on the long arm of chromosome $4 \mathrm{~A}$ as controlling the difference between two red-grained cultivars with widely different dormancy (Flintham et al., 2002). The PHS gene appeared to exert its effect in the embryo, in contrast to the $R$ gene expression in the maternal testa tissue. In the same arm, Anderson et al. (1993), Kato et al. (2001), Mares et al. (2002), Bassoi (2002) have identified two Quantitative Trait Loci (QTL) controlling seed dormancy. Moreover, Li et al. (2003) have found two QTLs for seed dormancy on chromosomes $2 \mathrm{H}$ and $5 \mathrm{HL}$ in barley. The major QTL for dormancy coincided with the QTL for pre-harvest sprouting at chromosome $5 \mathrm{HL}$ and explained $61 \%$ of the phenotypic variation.

The objective of this work was to assess genes for resistance to pre-harvest sprouting (PHS) in Brazilian wheat cultivars and to study their inheritance in T. aestivum.

\section{MATERIAL AND METHODS}

A $F_{2}$ population from the cross Frontana $x$ OR1 and its reciprocal were used in this study.
Frontana is an old, tall, red-grained cultivar with high level of seed dormancy and resistance to leaf rust and Fusarium Head Blight (FHB) and OR1 is a modern short, high-yielding red-grained cultivar with low dormancy, and susceptible to PHS. Genetic variation for dormancy was investigated in the parents, $F_{1}$ and 300 $\mathrm{F}_{2}$ lines derived from $\mathrm{F}_{1}$ hybrids grown at Embrapa Experimental Station, in Londrina, Paraná. When grains reached about $13 \%$ to $15 \%$ moisture content, at the harvest point, on September 4, a single head per plant was collected and seeds were tested for germinability and dormancy. Grains were gently threshed and germination/dormancy was immediately evaluated on wet paper towel rolls at $20^{\circ} \mathrm{C}$ for 5 days. For the test, two hundred seeds were used for $\mathrm{F}_{1}$ and parents, and 300 seeds for the $\mathrm{F}_{2}$ progenies of each cross. The germination was scored for number of sprouted grains with visible rupture of the pericarp. A $\chi^{2}$ analysis was performed to test for 3:1 and 15:1 ratios in the $\mathrm{F}_{2}$ progenies at $5 \%$ level of probability $(P<0.05)$.

\section{RESULTS AND DISCUSSION}

Germination of $F_{1}$ and $F_{2}$ seeds from crosses between dormant Frontana and non-dormant OR1 and their reciprocals were compared. A bimodal distribution for dormancy was observed in the $\mathrm{F}_{2}$ populations derived from Frontana $\times$ OR 1 and OR $1 \times$ Frontana crosses (Figure 2). The mean ratio of dormant to nondormant seeds over both types of crosses was 85:1115, fitting a digenic model of 1:15 $(P<0.05$, Table 1$)$. The $\chi^{2}$ for the pooled data, 1115 non-dormant: 85 dormant, was $1,42(\mathrm{df}=1, P<0.05)$. These results indicate that two major genes, hereinafter called $A, a$ and $B, b$, control seed dormancy, which appears to be recessive to dormancy. Only the homozygous $a a b b$ is dormant. In fact, all $F_{1}$ non after-ripened seeds, derived from Frontana $\times$ OR1 and its reciprocal, germinated, indicating that there is no effect of the maternal tissues (Table 1). Interestingly, the genes for dormancy in the dormant line from Canada, RL4137 (Frontana/3/ McMurachy/ Exchange//2*Redman), one of the cultivars most used to introduce PHS resistance in breeding programs in the world (Bassoi \& Flintham, 2005; Flintham, 1993) and the modern dormant Brazilian cultivar, BRS177 (PF83899/PF813//PF2714) came from FRONTANA. The line PF2714 is derived from Frontana. This allows us to suggest that most likely the genes for seed dormancy and PHS in wheat germplasm in the world come from Frontana's derived lines.

Only two cases of major gene, controlling PHS and dormancy, have been reported in wheat: the triplicate $R$ homoeoloci associated with red grain colour (Flintham \& Gale, 1996) and the locus Phs (Flintham, 


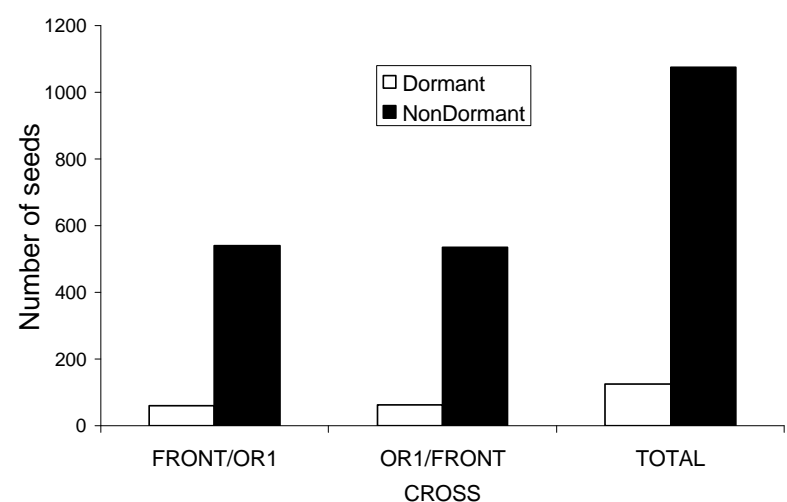

Figure 2 - The distribution of dormant and non-dormant seeds of the $F_{2}$ population from the Frontana $\times$ OR 1 cross and its reciprocal for seed germination at 5 days, Londrina, PR, Brazil.

Table 1 - Distribution of dormant and non-dormant seeds of the $\mathrm{F}_{2}$ population from the Frontana $\times \mathrm{OR} 1$ cross and its reciprocal for seed germination at 5 days, Londrina, PR, Brazil, 2004.

\begin{tabular}{lccc}
\hline \multicolumn{4}{c}{ Seed } \\
\hline Crosses & Dormant & Non-dormant & $\begin{array}{c}\chi^{2} \text { analysis } \\
(\mathrm{df}=1)\end{array}$ \\
\hline Frontana $\times$ OR1 $^{1}$ & $20-21$ & $280-279$ & $0.088-0.227 *$ \\
OR1 $\times$ Frontana & $21-23$ & $279-277$ & $0.227-0.91 *$ \\
\hline Total & 85 & 1115 & $1.42 *$ \\
\hline
\end{tabular}

${ }^{1}$ The germination of the parents was: Frontana $1 \%$ and OR1 was $98 \%$. Germination of $\mathrm{F}_{1}$ was $96 \%$. *At $5 \%$ level of significance.

2000). It is evident that red grain colour and dormancy are not phenotypes of the same pleiotropic gene as it has been reported by Flintham et al. (2002), since $R$ alleles do not fully guarantee dormancy in wet conditions.

Thus, the plant breeding strategy for introducing resistance to pre-harvest sprouting in wheat is to incorporate major genes from Frontana or derived lines, such as RL 4137 or BRS 177, into modern breeding lines.

\section{CONCLUSIONS}

The $\mathrm{F}_{2}$ distribution indicates that dormancy in this cross appeared to be recessive and two major genes, $A, a$ e $B, b$, are involved in the control of seed dormancy. Only the homozygous $a a b b$ is dormant. As expected, there was no effect of maternal tissues.

\section{REFERENCES}

ANDERSON, J.A.; SORREL, M.E.; TANKSLEY, S.D. RFLP analysis of genomic regions associated with resistance to pre harvest sprouting in wheat. Crop Science, v.33, p.453-459, 1993.

BASSOI, M.C. Quantitative trait analysis of grain dormancy in wheat (Triticum aestivum L. Thell). Norwich: John Innes Centre \& University of East Anglia, 2002. 240p. (Ph.D. - Thesis).

BASSOI, M.C.; FLINTHAM, J. Relationship between grain colour and preharvest sprouting in wheat. Pesquisa Agropecuária Brasileira, v.40, p. 981-988, 2005.

FLINTHAM, J.E. Grain colour and sprout-resistance in wheat. In: WALKER-SIMMONS, M.K.; RIED, J.L. (Ed.). Pre-harvest sprouting in cereals. 6.ed. Saint Paul: American Association of Cereal Chemists, 1993. p.30-36.

FLINTHAM, J.E. Different genetic components control coat-imposed and embryo-imposed dormancy in wheat. Seed Science Research, v.10, p.43-50, 2000.

FLINTHAM, J.E.; GALE, M.D. Genetics of pre harvest sprouting and associated traits in wheat. Plant Varieties \& Seeds, v.1, p.87-97, 1988.

FLINTHAM, J.E.; GALE, M.D. Dormancy gene maps in homoeologous cereal genomes. In: NODA, K.; MARES, D.J. (Ed.). Pre-harvest sprouting in cereals. Tokyo: Center for Academic Societies, 1996. p.143-149

FLINTHAM, J.E.; ADLAM, R.E.; BASSOI, M.C.; HOLSWORTH, M.; GALE, M.D. Mapping genes for resistance to sprouting damage in wheat. Euphytica, v.126, p.39-45, 2002.

KATO, K.; NAKAMURA, W.; TABIKI, T.; MIURA, H.; SAWADA, S. Detection of loci controlling seed dormancy on group 4 chromosomes of wheat and comparative mapping with rice and barley genomes. Theoretical \& Applied Genetic, v.102, p.980-985, 2001.

LAWSON, W.R.; GOWIN, I.D.; COOPER, M.; BRENNAN, P.S. Genetic analysis of pre harvest sprouting tolerance in three wheat crosses. Australian Journal of Agricultural Research, v.48, p.215-221, 1997.

LI, C.D.; TARR, A.; LANCE, R.C.M.; HARASYMOW, S.; UHLMANN, J.; WESTOR, S.; YOUNG, K.J.; GRIME, C.R.; CAKIR, M.; BROUGHTON, S.; APPELS, R. A major QTL controlling seed dormancy and pre-harvest sprouting/grain $\alpha$-amylase in two-rowed barley (Hordeum vulgare L.). Australian Journal of Agricultural Research, v.54, p.1303-1313, 2003.

MARES, D.J.; MRVA, K.; TAM, M.; SHARP, P. Dormancy in whitegrained wheat: Progress towards identification of genes and molecular markers. Euphytica, v.126, p.47-53, 2002.

Received November 11, 2005

Accepted October 02, 2006 